\title{
Yoğun Bakımdan Taburcu Olan Tıbbi Teknolojiye Bağımlı Çocuklara Verilen Evde Bakım Hizmetlerinin Değerlendirilmesi
}

\section{Evaluation of Home Care Services Given to Medical Technology-Dependent Children That Were Discharged From Intensive Care Unit}

\author{
Duygu SÖNMEZ DÜZKAYA ${ }^{\text {iD }}$ Gülçin BOZKURT ${ }^{\text {b }}$ BD Tülay YAKUT $^{\text {iD }}$
}

ÖZET Amaç: Bu çalışma, bir üniversite hastanesinin Çocuk Yoğun Bakım Ünitesinden taburcu edilen tıbbi teknolojiye bağımlı çocuklara verilen evde bakım hizmetlerini değerlendirmek amacıyla yapıldı. Gereç-Yöntem: Tanımlayıcı tipte gerçekleştirilen araştırmanın evrenini; İstanbul Üniversitesi İstanbul Tıp Fakültesi Hastanesi, Çocuk Yoğun Bakım Ünitesinden taburcu edildikten sonra evde bakılan 42 hasta, örneklemi ise çalışmaya katılmayı kabul eden 30 hasta oluşturdu. Veriler araştırmacılar tarafindan literatür doğrultusunda hazırlanan "Veri Toplama Formu" ile elde edildi. Veri toplama formu; hastaların yoğun bakım ünitesine trakeostomi kanül değişimi, nazoduodenal sonda değişimi vb ihtiyaçları nedeniyle getirildiğgi sırada veya aileler ile yapılan telefon görüşmesi ile araştırmacılar tarafindan dolduruldu. Bulgular: Çalışma grubundaki çocukların; ortalama yaşının $85.63 \pm 58.40$ ay olduğu, \%56.7'sinin erkek ve \%40'ının nörolojik hastalık tanısı ile takip edildiği saptandı. Yoğun bakımdan taburcu edilen çocukların tamamının trakeostomisi olduğu, \%96.7'sinin ev tipi mekanik ventilatör kullandığı ve \%93.3'ünün enteral yolla beslendiği belirlendi. Taburcu edildikten sonra hastaların \%56.7'sinin yoğun bakıma tekrar yattı̆̆ı belirlendi. Ailelerin \% 86.7'sinin evde sağlık hizmetleri koordinasyon merkezine başvurduğu ancak yalnızca \%36.7'sinin bu birimlerden destek hizmet aldığı ve alınan hizmetin en çok \%23.3 oranında tıbbi tedavi veya izlem olduğu görüldü. Evde bakım hizmetleri ekipleri tarafindan; trakeostomi değişimi, trakeostomi bakımı, aspirasyon, nazogastrik/orogastrik sonda takma, idrar sondası takma, egzersiz, vücut bakımı vb. yapılmadığı belirlendi. Ailelerin \%93.3'ü evde acil durumlarda geri döndürülemeyecek sorunlar ile karşılaşabileceklerini bildirmiştir. Sonuç: Yoğun bakımdan taburcu edilen tıbbi teknolojiye bağımlı çocuklar evde bakım hizmetleri ekiplerinden yeterince yararlanamamaktadırlar. Bu hastaların evde bakımları aileleri tarafindan yapılmaktadır. Tıbbi teknolojiye bağımlı yoğun bakım hastalarına yönelik evde bakım hizmetlerinin geliştirilmesi önerilebilir.

Anahtar Kelimeler: Evde bakım, çocuk, tıbbi teknoloji, yoğun bakım

\begin{abstract}
Aim: To evaluate home care services given to medical technology-dependent children that were discharged from Pediatrics Intensive Care Unit of a university hospital. Material-Method: The research design was a descriptive study. The target population was 42 patients who were discharged from Pediatric Intensive Care Unit in Istanbul University, Istanbul Faculty of Medicine for home care, and the sample was 30 patients who gave consent for the study. Researchers obtained tha data using the "Data Collection Form", that was prepared in accordance with the literature. Data collection form; were filled in by the investigators at the time of bringing in the intensive care unit of the patients due to the needs of tracheostomy cannula exchange, nasoduodenal probe replacement etc, or by telephone interview with the families. Results: The mean age in the study group was $85.63 \pm 58.40$ months, and $56.7 \%$ were male, and $40 \%$ were followed-up due to neurologic diseases. All children that were discharged from intensive care unit had tracheostomy, $96.7 \%$ of patients used home mechanical ventilator, and $93.3 \%$ received enteral feeding. Researchers found that $56.7 \%$ were rehospitalised in intensive care after discharge from hospital. Although, $86.7 \%$ of families applied to home care health services coordination center, only $36.7 \%$ received suppport services, and the most services with $23.3 \%$ was medical treatment or followup. Researchers found that home care service team did not perform practises such as tracheostomy tube change, tracheostomy tube care, suction, nasogastric/orogastric catheter insertion, urinary catheter insertion, exercises, body care. Researchers found that $93.3 \%$ of families reported that irreversible problems would be experienced at home in case of emergencies. Conclusion: Medical technology-dependent children who are discharged from intensive care unit can not benefit enough from home care services teams. The families provide the home care of
\end{abstract}

Geliş Tarihi/Received: 30-05-2017/ Kabul Tarihi/Accepted:23-09-2017

${ }^{a}$ Dr. İstanbul Tıp Fakültesi Hemşirelik Hizmetleri Müdürlüğü İstanbul Üniversitesi İstanbul Tıp Fakültesi, Hemşirelik Hizmetleri Müdürlügü Dekanlık Binası Kat:2 Fatih, İstanbul, Türkiye, Tel: +90 21241420 00-31458 e.posta: dygsnmz@ hotmail.com, ORCID ID:0000-0002-1815-8821

b bDoç. Dr.İ́stanbul Üniversitesi Sağlık Bilimleri Fakültesi Ebelik Bölümü, e.posta: gbozkurt@istanbul.edu.tr ORCID ID:0000-0002-8528-2232

c İstanbul Üniversitesi İstanbul Tıp Fakültesi Çocuk Yoğun Bakım Bilim Dalı

e.posta: tulayyakut76@yahoo.com.tr ORCID ID:/0000-0003-1546-3406

Sorumlu yazar /Correspondence: Dr. Duygu Sönmez Düzkaya, İstanbul Tip Fakültesi Hemşirelik Hizmetleri Müdürlüğü, İstanbul Üniversitesi İstanbul Tıp Fakültesi, Hemşirelik Hizmetleri Müdürlüğü Dekanlık Binası Kat:2 Fatih, İstanbul, Türkiye,e.posta: $\underline{\text { dygsnmz@ hotmail.com }}$ 
these patients. The development of home care services for intensive care patients dependent on medical technology may be recommended.

Key words: Home care, pediatrics, medical technology, intensive care

\section{Giriş}

Yoğun bakım ünitelerindeki teknolojik gelişmeler ve eğitimli personel sayısının artmasina paralel olarak kritik hastalar daha uzun yaşamaktadır. Kronik solunum yetmezliği gelişen kritik hasta çocuklarda mekanik ventilatör ile sağlanan solunum desteği standart tedavi yöntemi olarak kabul edilmektedir. ${ }^{1-3}$ Kronikleşen yoğun bakım hastalarının sınırlı olan yoğun bakım yataklarını kullanması, ekonomik kayıplar ve hasta yükünün artmasına yol açmaktadır. Sınırlı sayıdaki yoğun bakım yatak kapasitesini daha verimli kullanmak, hastanın aile ortamına dönmesi ile moral desteği sağlamak, yoğun bakımda uzun süre kalmaya bağlı mortalite, morbidite ve sağlık harcamalarını azaltmak, solunum fonksiyonlarını korumak, egzersiz kapasitesini arttırmak, enfeksiyon gibi yatış süresini arttıran komplikasyonları azaltmak ve yaşam kalitesini koruyup yükseltmek amaciyla acil durum ve yaşamsal fonksiyonları düzelen, stabil yoğun bakım hastasının evde bakımı önerilmektedir. ${ }^{1,3-}$

Yoğun bakım teknolojilerinin gelişmesi ile birlikte birçok ülkede ev tipi mekanik ventilatöre bağlı hasta sayısının giderek arttığı bildirilmektedir. $^{2}$ Ancak, ev tipi mekanik ventilatöre bağlı hasta sayısı ile ilgili veriler oldukça faklılık göstermektedir. Amerika ve Avrupa'da evde ventilatöre bağlı bakım verilen hasta sayısının giderek arttığ bildirilmektedir. Evde bakılan hastalara ait veriler değerlendirildiğinde; Avrupa genelinde her 100.000 kişiden 6.6'sının', Avusturalya'da 9.9'unun, Yeni Zelanda'da 12 ' $\operatorname{sinin}^{7}$ evde mekanik ventilatöre bağlı yaşadığ 1 belirlenmiştir. ${ }^{8}$ Polonya'da evde ventilatöre bağlı olan hastaların \%3'ünün çocuk hasta olduğu bildirilmiştir. ${ }^{8}$ Türkiye' de ventilatöre bağlı evde bakılan çocuk sayısı bilinmemektedir. ${ }^{9}$

Ülkemizde taburculuk planlamasının ve evde bakım hizmetlerinin yeterli olmaması nedeniyle hastaların hastanede kalış süreleri uzamaktadır. ${ }^{3}$ Kronik hastalığ 1 olan ve uzun süreli bakım gereksinimi olan hastaların hastane yerine evde bakılmasının sağlık finansmanı açısından avantajlı olduğu vurgulanmaktadır. Amerika'da mekanik ventilatöre bağl1 yoğun bakım hastasının günlük bakım maliyetinin 6001500 dolar arasında değiştiği, ${ }^{10,11}$ yoğun bakımda aylık sağlık bakım maliyetinin 21,570 dolar olduğu, bu hastaların evde bakımında ise 7,050 dolar harcandığı ve evde bakımın teşvik edilmesi gerektiği vurgulanmaktadır. ${ }^{12}$

Kronik ventilasyon tedavisi gereken çocuklar evde bakım için gerekli araçlar temin edilerek eve taburcu edilmektedir. ${ }^{3,5}$ Ev tipi ventilatörlerin gelişmesi, pratikleşmesi, kullanım kolaylığı ve anlaşılırlığının artması ile hastanın bakımını evde sürdürme isteği artmaktadır. Evde bakım hizmetlerinin gelişmesi ile çocukların eve taburculuğunun kolaylaşacağ 1 , hastane tekrar yatışlarının azalacağı gösterilmiştir. ${ }^{13}$ Tıbbi teknolojiye bağımlı çocuklara verilen evde bakım hizmetleri ile ilgili mevcut durumun ve yaşanan güçlüklerin belirlenmesi, yoğun bakımdan taburcu edilen hastalara daha kaliteli hizmet verilmesine katkı sağlayacaktır.

$\mathrm{Bu}$ çalışma bir üniversite hastanesinin çocuk yoğun bakım ünitesinden taburcu edilen, tıbbi teknolojiye bağımlı çocuklara verilen evde bakım hizmetlerini değerlendirmek amacıyla yapıldı.

\section{Yöntem}

Araştırmanın tipi: Tanımlayıcı özellikteki araştırmanın verileri, İstanbul Üniversitesi İstanbul Tıp Fakültesi Hastanesi, Çocuk Yoğun Bakım Ünitesinden taburcu edilen, evde bakılmakta olan çocukların ailelerinden elde edildi.

Araştırma evreni ve örneklemi: Araştırmanın evrenini; İstanbul Üniversitesi İstanbul Tip Fakültesi Hastanesi, Çocuk Yoğun Bakım Ünitesinden taburcu edildikten sonra evde bakılan 42 çocuğun ailesi, örneklemini ise çalışmaya katılmayı kabul eden 30 çocuğun ailesi oluşturdu. Çalışmada örneklem seçimine gidilmeden, iletişim kurulabilen, çalı̧̧maya katılmayı kabul eden bütün aileler çalışmaya dahil edildi. 12 aile görüşmeyi kabul etmediği için çalışma dışında bırakıldı. Örneklem grubundaki ailelerin 26'si İstanbul Tip Fakültesi Hastanesine uzak ilçelerde (Eyüp, Esenler, Bağcılar, Sultangazi, Küçükçekmece, Halkal1, Büyükçekmece, Avcılar, Kayaşehir, Hadımköy, 
Kağıthane, Taksim, Şişli, Okmeydanı, Ümraniye, Beykoz), 2'si hastanenin bulunduğu ilçe veya yakınında (Fatih, Zeytinburnu) ve 2'si ise şehir dışında yaşamakta idi.

Veri toplama: Araştırmada veriler araştırıcılar tarafindan literatürden yararlanarak ${ }^{2,6,8,13}$ oluşturulan "Veri Toplama Formu" kullanılarak elde edildi. Veri toplama formu 28 sorudan ve üç bölümden oluştu. Birinci bölümde çocuk ve aileye yönelik tanitıcı bilgileri içeren sorular (çocuğun yaşı ve hastaneye yatış tanısı, ebeveynlerin yaşı, eğitim düzeyi vb.), ikinci bölümde hastanede yapılan uygulamalara yönelik sorular (taburculuğa hazır olma durumu, kullanılan cihazlar, eve taburculuk şekli vb.) ve üçüncü bölümde ise taburculuk sonrasında yaşananlara (evde bakım hizmetlerine ilişkin sorular, ailelerin evde bakım ile yoğun bakımın avantaj ve dezavantajlarına ilişkin görüşleri vb.) ilişkin kapalı uçlu sorular yer aldı. Veri toplama formu; hastaların yoğun bakım ünitesine trakeostomi kanül değişimi, nazoduodenal sonda değişimi vb ihtiyaçları nedeniyle getirildiği sırada veya aileler ile yapılan telefon görüşmesi ile araştırmacılar tarafindan dolduruldu. Her bir soru formunun doldurulması ortalama $15 \mathrm{dk}$ sürdü.

Verilerin analizi: Elde edilen veriler Statistical Package for Social Sciences (SPSS) 21.0 paket programında; sayı, yüzde ve ortalama istatistiksel testler kullanılarak analizleri yapıldı.

Çalışmanın etik yönü: Çalışmanın yapılabilmesi için İstanbul Üniversitesi İstanbul Tıp Fakültesi Hastanesi, Çocuk Yoğun Bakım Ünitesinden ve hastane yönetiminde gerekli kurum izinleri alındı. İstanbul Üniversitesi İstanbul Tıp Fakültesi Klinik Araştırmaları Etik Kurulundan etik kurul onayı (Karar No:12) alındı. Çalışmaya katılımda gönüllülük ilkesine dikkat edilerek, çalışma öncesinde ailelere çalışmanın amacı ile ilgili bilgi verildi ve bilgilendirilmiş olur doğrultusunda yazılı ve sözlü onamları alındı.

Araştırmanın Sınırlııkları: Araştırmanın bulguları, İstanbul Üniversitesi İstanbul Tip Fakültesi Hastanesi, Çocuk Yoğun Bakım Ünitesinden taburcu edilen çocukların ailelerinden alındığından ülke geneline yansıtılamaz.

\section{Bulgular}

Çocuk Yoğun Bakım Ünitesinden taburcu edilen ve evde bakılan çocukların; ortalama yaşının $85.63 \pm 58.40$ (min-max:15-216) ay, \%56.7'sinin $(n=17)$ erkek ve \%43.3'ünün ( $n=13)$ kız olduğu, annelerin ortalama yaşının $35.13 \pm 6.48$ (minmax:28-53) yıl, babaların ortalama yaşının ise $39.23 \pm 6.38$ (min-max: 28-53) y1l olduğu saptandi.

Çalışma grubundaki çocukların tanıları incelendiğinde; \%40'ının ( $=12)$ nörolojik hastalık, \%36.7'sinin ( $\mathrm{n}=11)$ metabolik hastalik, $\% 10$ 'unun $(\mathrm{n}=3)$ suda boğulma ve \%6.7'sinin $(n=2)$ post-op ekstübe olamama ve enfeksiyon hastalığı tanıları ile yoğun bakım ünitesinde tedavi olduğu belirlendi.

Tablo 1. Tıbbi Teknolojiye Bağımlı Çocuklar ve Ailelerin Özellikleri $(\mathrm{n}=30)$

\begin{tabular}{|c|c|c|}
\hline Özellikler & $\begin{array}{l}\text { Dağılım } \\
\text { aralığ̀ }\end{array}$ & Ort \pm SS \\
\hline $\begin{array}{l}\text { Yoğun bakımda } \\
\text { yatma süresi (gün) }\end{array}$ & $15-180$ & $64.43 \pm 42.45$ \\
\hline $\begin{array}{l}\text { Serviste yatış süresi } \\
\text { (gün) }\end{array}$ & $7-210$ & $46.78 \pm 58.78$ \\
\hline \multirow[t]{2}{*}{$\begin{array}{l}\text { Evde bakım süresi } \\
\text { (ay) }\end{array}$} & 4-94 & $27.40 \pm 21.16$ \\
\hline & $\mathrm{n}$ & $\%$ \\
\hline \multicolumn{3}{|l|}{ Annenin eğitimi } \\
\hline İlköğretim & 16 & 53.3 \\
\hline Ortaöğretim & 9 & 30.0 \\
\hline Yükseköğretim & 5 & 16.7 \\
\hline \multicolumn{3}{|l|}{ Babanın eğitimi } \\
\hline İlköğretim & 9 & 30.0 \\
\hline Ortaöğretim & 14 & 46.7 \\
\hline Yükseköğretim & 7 & 23.3 \\
\hline \multicolumn{3}{|l|}{$\begin{array}{l}\text { Ebeveynlerin çalışma } \\
\text { durumu }\end{array}$} \\
\hline Anne çalışmıyor & 30 & 100 \\
\hline Baba çalışmıyor & 3 & 10 \\
\hline \multicolumn{3}{|l|}{ Aile Tipi } \\
\hline Çekirdek aile & 27 & 90 \\
\hline Geniş aile & 3 & 10 \\
\hline \multicolumn{3}{|l|}{ Ailenin gelir durumu } \\
\hline Gelir $<$ Giderden & 15 & 50 \\
\hline Gelir=Gidere & 14 & 46.7 \\
\hline Gelir > Giderden & 1 & 3.3 \\
\hline
\end{tabular}

Ailelere ilişkin tanımlayıcı özellikler tablo 1'de verilmiştir. Yoğun bakım sonrası evde bakılan çocukların; yoğun bakımda ortalama $64.43 \pm 42.45$ (min-max: 15-180) gün yattı̆ğ, 
evde ise ortalama $27.40 \pm 21.16$ (min-max:4-94) ay bakıldığı saptandı (Tablo 1).

Tablo 2. Evde Bakıma Yönelik Taburculuğa Hazırlık $(\mathrm{n}=30)$

\begin{tabular}{lcc}
\hline Hazırlık özellikleri & $\mathrm{n}$ & $\%$ \\
\hline Evde kullanılan destek sistemleri & & \\
Trakeostomi & 30 & 100 \\
Ev tipi mekanik ventilatör & 29 & 96.7 \\
Gastrostomi & 11 & 36.7 \\
Nazogastrik/ orogastrik & 17 & 56.7
\end{tabular}

Evde bakıma kim hazırladı

Hemşireler

$24 \quad 80.0$

Doktorlar

$6 \quad 20.0$

Hastaneden eve gidiş şekli

Kendi imkânları

Evde sağlık hizmetleri

koordinasyon merkezinin desteği

112 ambulans1

Belediye ambulansı

$2 \quad 6.7$

$19 \quad 63.3$

26.7

Taburculuğa hazır olma durumları

Taburculuğa hazır

Taburculuğa hazır değil

$22 \quad 73.3$

$\begin{array}{ll}8 & 26.7\end{array}$

Taburculuktan sonra tekrar yoğun

bakıma yatma

Tekrar yatış var

Tekrar yatış yok

$\begin{array}{ll}17 & 56.7\end{array}$

$13 \quad 43.3$

Taburculuktan sonra tekrar yoğun

bakıma yatma $(\mathrm{n}=17)$

1 kez yoğun bakıma yattı

2 kez yoğun bakıma yattı

3 kez ve daha fazla yoğun bakıma yatt1

Taburculuğa hazırlanırken

ebeveynlere verilen eğitimler

Bakım uygulamaları

Kullanılan araçlar

Acil durumda yapılacaklar

Aspirasyon

Beslenme

Tedavi uygulamaları

Trakeostomi bakımı

Yara bakımı ve enfeksiyonları

önleme

Temel yaşam desteği uygulamaları

$\begin{array}{ll}30 & 100 \\ 30 & 100 \\ 30 & 100 \\ 30 & 100 \\ 30 & 100 \\ 28 & 93.3 \\ 28 & 93.3 \\ 27 & 90.0 \\ & \\ 19 & 63.3\end{array}$

Tablo 2'ye bakıldığında; çocukların tamamının trakeostomi ile taburcu edildiği, \%96.7'sinin ev tipi mekanik ventilatör kullandığ 1 ve \%93.3'ünün enteral beslenme destek sistemlerini kullandığı görüldü (Tablo 2). Evde bakılan çocukların \%6.6'sının ( $\mathrm{n}=2)$ oral olarak beslendiği belirlendi.

Taburculuğa hazırlanırken bakım verecek ebeveynlere verilen eğitimler incelendiğinde; bakım uygulamaları, kullanılan araçlar, acil durumda yapilacaklar, aspirasyon ve beslenme konularında ailelerin tamamına bilgi verildiği, \%93.3'üne $(\mathrm{n}=28)$ tedavi uygulamaları ve trakeostomi bakımı ve \%90'nına $(n=27)$ yara bakımı ve enfeksiyonları önlemeye yönelik eğitimleri verildiği belirlendi (Tablo 2).

Tablo 3. Evde Bakım Hizmetlerine İlişkin Bilgi ve Yararlanma Durumu $(\mathrm{n}=30)$

\begin{tabular}{lll}
\hline $\begin{array}{l}\text { Hizmetlerden yararlanma } \\
\text { durumu }\end{array}$ & $\begin{array}{l}\text { Evet } \\
\%(\mathrm{n})\end{array}$ & $\begin{array}{l}\text { Hayır } \\
\%(\mathrm{n})\end{array}$ \\
\hline $\begin{array}{l}\text { Evde sağlı hizmetleri } \\
\text { koordinasyon merkezinin } \\
\text { numarasını biliyor mu? }\end{array}$ & $50.0(15)$ & $50.0(15)$ \\
$\begin{array}{l}\text { Evde sağlı hizmetleri } \\
\text { koordinasyon merkezine } \\
\text { başvurmuş mu? }\end{array}$ & $86.7(26)$ & $13.3(4)$ \\
$\begin{array}{l}\text { Evde sağlık hizmetleri } \\
\text { koordinasyon } \\
\text { merkezinden hizmet } \\
\text { alıyor mu? }\end{array}$ & $36.7(11)$ & $63.3(19)$ \\
$\begin{array}{l}24 \text { saat arayabileceği } \\
\text { evde bakım ekibi var mı? }\end{array}$ & - & $100(30)$ \\
$\begin{array}{l}\text { Evde bakım ve tedavi } \\
\text { için gerekli tıbi cihaz/ } \\
\text { malzeme ve ilaçlara } \\
\text { kolay ulaşıyor mu? }\end{array}$ & $86.7(26)$ & $13.3(4)$ \\
$\begin{array}{l}\text { Çocuğun bakımı için } \\
\text { maddi destek alıyor mu? }\end{array}$ & $60.0(18)$ & $40.0(12)$ \\
\hline
\end{tabular}

Taburculuk sonrası çocuğun bakımının, $\% 90 \quad(\mathrm{n}=27)$ anneler, \%10 (n=3) babalar tarafından yapıldığı, hiçbir çocuğun bakımını destekleyen bakıcısının olmadığı saptandı. Tablo 3'te evde bakım hizmetlerinden yararlanma durumuna ilişkin veriler incelendiğinde; ailelerin \%86.7'sinin evde sağl1k hizmetleri koordinasyon merkezine başvurduğu, ancak \%36.7'sinin evde sağlik bakım hizmetlerinden yararlandığ 1 görüldü (Tablo 3). Taburcu olduk-tan sonra evde sağlik hizmetleri koordinasyon merkezi tarafindan çocuğa verilen hizmetler irdelendiğinde; ailelerin \%60'1 (n=18) hiçbir hizmet verilmediğini, \%23.3'ü $(\mathrm{n}=7)$ tıbbî tedavi/takip, \%6.7'si (n=2) fizyoterapi, \%6.7'si (n=2) bakim hizmeti ve bir kişinin de ambulans hizmeti almış olduğu belirlendi. Evde bakım hizmetleri ekipleri tarafindan verilen hizmetler değerlendirildiğinde; sekiz hastanın laboratuvar tetkikleri için kanının alındığı, iki hastaya yara bakımı yapıldığı ve bir hastaya ise psikolojik 
destek verildiği görüldü. Ailelerin evde bakım hizmetleri ekipleri tarafından; trakeostomi değişimi, trakeostomi bakımı, aspirasyon, nazogastrik/orogastrik sonda takma, idrar sondas1 takma, egzersiz, vücut bakımı vb. yapılamadığını ifade ettikleri ve bu uygulamaları kendilerinin yaptığı ya da tekrar bu işlemler için hastaneye geldikleri belirlendi.

Tablo 4. Ebeveynlerin Evde Bakım ile Yoğun Bakımın Avantaj ve Dezavantajlarını Karşılaştırmalarına Yönelik Görüşleri $(\mathrm{n}=30)$

\begin{tabular}{lll}
\hline Aile görüşleri & $\begin{array}{l}\text { Yoğun } \\
\text { bakım } \\
\text { (n) }\end{array}$ & $\begin{array}{l}\text { Evde } \\
\text { bakım } \\
\%(\mathrm{n})\end{array}$ \\
\hline $\begin{array}{l}\text { Hasta daha fazla risk } \\
\text { altında }\end{array}$ & $70.0(21)$ & $30.0(9)$ \\
$\begin{array}{l}\text { Aile üyelerinde stres } \\
\text { yaratabilir }\end{array}$ & $80.0(24)$ & $20.0(6)$ \\
$\begin{array}{l}\text { Acil durumlarda geri } \\
\text { döndürülemeyecek } \\
\text { sonuçlar olabilir }\end{array}$ & $6.7(2)$ & $93.3(28)$ \\
$\begin{array}{l}\text { Enfeksiyon daha az } \\
\text { görülür }\end{array}$ & $23.3(7)$ & $76.7(23)$ \\
$\begin{array}{l}\text { Tedavi ve bakım maliyeti } \\
\text { daha düşüktür }\end{array}$ & $73.0(22)$ & $26.7(8)$ \\
$\begin{array}{l}\text { Hastalar fonksiyonel } \\
\text { olarak gerçek } \\
\text { ortamlarında } \\
\text { değerlendirilir }\end{array}$ & - & $100(30)$ \\
$\begin{array}{l}\text { Hastanın yaşam kalitesi } \\
\text { artar }\end{array}$ & - & $100(30)$ \\
$\begin{array}{l}\text { İyileşme daha hızlı olur } \\
\text { Hastanın sorunları daha } \\
\text { erken saptanır }\end{array}$ & $10.0(3)$ & $90.0(27)$ \\
$\begin{array}{l}\text { Ölmek üzere olan } \\
\text { hastaların fiziksel ve } \\
\text { psikolojik rahatlığı } \\
\text { desteklenir }\end{array}$ & $26.7(8)$ & $73.3(22)$ \\
\hline
\end{tabular}

Tablo 4'te ebeveynlerin evde bakım ile yoğun bakımın avantaj ve dezavantajlarını karşılaştırmalarına yönelik görüşleri incelendiğinde; yoğun bakımda ailelerin; \%70'i hastaların daha fazla risk altında olduğunu ve $\% 80$ 'i aile üyelerinde stres olacağını yoğun bakım için dezavantaj olarak belirttikleri saptandi. Evde bakım açısından ise \%93.3'ü evde acil durumlarda geri döndürülemeyecek sonuçların olacağını dezavantaj olarak ifade ettikleri belirlendi (Tablo 4).

\section{Tartışma}

Uzun süreli tıbbi teknolojiye bağımlı, stabil hastaların yaşam kalitelerini arttırmak, bakım maliyetlerini azaltmak ve yoğun bakım yataklarını etkin bir şekilde kullanmak için evde bakılmasının daha uygun olduğu vurgulanmaktadır. ${ }^{14}$ Ancak evde bakılacak yoğun bakım hastalarının ev koşullarının hastaya uygun hazırlanmas1, hastaya bakacak kişilerin eğitilmesi, hastanın ve ailesinin gereksinimi olan evde sağlık hizmetleri desteğinin sağlanması gerekmektedir.

$\mathrm{Bu}$ çalışmada yoğun bakım ünitesinden taburcu edilen ve ev tipi mekanik ventilatöre bağlı olduğu için evde bakım gereksinimi olan çocukların \%40'ının nörolojik hastalık tanısı ile taburcu edildiği belirlenmiştir. Ülgen Tekerek ve ark. ${ }^{1}$ ev tipi mekanik ventilatöre bağlı hastalarının \%86.7'sının ilk sırada nörolojik hastalıklar tanısı ile taburcu edildiğini saptamıştır. Evde mekanik ventilatöre bağımlı olan hastaların Polanya'da $\% 34^{8}$ ve Avusturalya'da ise \%30 oranında ilk sirada nörolojik hastalık tanısı olduğu bildirilmektedir. ${ }^{7}$ Benzer hasta sonuçları ile karşılaştırıldığında, ev tipi mekanik ventilatöre bağlı hastaların en çok nörolojik hastalık tanıs1 aldığı görülmektedir.

Yoğun bakımdan taburcu olan tıbbi teknolojiye bağımlı hastalar evde bakım ihtiyacı olan en kompleks hastalardır. Bu hastaların genelde ciddi beslenme ve solunumsal problemleri mevcuttur. ${ }^{13}$ Ayar ve ark. ${ }^{13}$ evde bakılan çocukları değerlendirdiği çalışmasında, hastaların \%71.4'ünün gastrostomi, nazogastrik sonda ve ev tipi ventilatör gibi en az bir tıbbi teknolojiye bağımlı olduğunu belirlemiştir. Çalışma grubumuzdaki hastaların; tamamının trakeostomili, \%96.7'si ev tipi mekanik ventilatöre bağlı ve \%93.4'ünün gastrostomi veya nazogastrik yolla enteral olarak beslendiği saptandı. Yoğun bakımdan taburcu edilen hastaların evde bakılan diğer hasta gruplarına göre daha çok tıbbi teknolojilere (mekanik ventilatör, enteral beslenme) bağımlı olduğu ve evde bakım gereksinimlerinin daha fazla olduğu göz önünde bulundurulmalıdır.

Tıbbi teknolojiye bağımlı hastanın evde bakımını gerçekleştirecek kişilerin hazır olmaması ya da isteksiz olmaları stabil yoğun bakım hastalarının hastanede yatış süresini uzatmaktadır. Ülgen Tekerek ve ark. ${ }^{1}$ Erciyes Üniversitesi Çocuk Yoğun Bakım Ünitesinden 
Ev Tipi Mekanik ventilatör (EMV) ile taburcu ettikleri 29 çocuk hastanın yoğun bakımda ortalama 75 gün yattığını saptamıştır. Hastalarımızın yoğun bakımda ortalama yatış süresi $64.43 \pm 42,45$ gün idi. Sağlıkta dönüşümle birlikte stabil yoğun bakım hastalarının hastanede yatış süresinin kısa tutulması, evde bakımının desteklenmesi önerilmektedir. Ülkemizde yoğun bakımdan taburcu edilen tıbbi teknolojiye bağımlı hastanın eve geçiş süresini kısaltacak çalışmalar yapılması gerekmektedir. Evde bakım hastalarına yönelik bakım gereksinimini karşılayacak hizmetler geliştirilmelidir.

Yoğun bakımdan eve geçen tıbbi teknolojiye bağımlı hastanın tedavi ve bakımı, yoğun bakım ekibi ve evde bakım hizmetlerini yürüten ekibin işbirliği ile yürütmelidir. ${ }^{15,16}$ Stabil yoğun bakım hastasının eve geçişi için hastanın, ailenin ve ev ortamının hazırlanması gerekmektedir. Ülgen Tekerek ve ark. ${ }^{1}$ yoğun bakımdan taburcu olacak hastaların ailelerine evde yapılacak tedavi ve bakımlar ile ilgili yapılan bir haftalık eğitim sonunda; aspirasyon, trakeostomi ve postural drenaj1 başarı ile yapabildiklerini saptamıştır. Ünitemizde takip edilen çocuklara trakeostomi açılma kararı alındığ1 andan itibaren, ailelere trakeostomi açılma nedeni ve yapılan işlemler hakkında bilgi verilerek, bakıma katılmaları sağlanmaktadır. Ailelerin tamamı kendilerine taburculuğa hazırlık kapsamında; bakım uygulamaları, kullanılan araçlar, acil durumda yapılacaklar, temel yaşam desteği, aspirasyon ve beslenme konularında bilgi verildiğini; tedavi uygulamalar1 ve trakeostomi bakımı \%93.3, yara bakımı ve enfeksiyonları önleme $\% 90$ ve temel yaşam desteği uygulamaları konusunda ise \%63.3'ü bilgilendirildiklerini belirtmiştir. Yoğun bakımdan taburcu edilen tıbbi teknolojiye bağımlı hastanın evde bakımı daha fazla deneyim gerektirmektedir. Ailelerin beceri kazanması için aile merkezli bakım yaklaşımı kapsamında hastanın yoğun bakıma kabul edildiği andan itibaren bakıma katılması önerilmektedir. ${ }^{4}$ Tıbbi teknolojiye bağımlı hasta ailelerinin evde bakıma hazırlanmasına yönelik yapılan eğitimler ile ilgili çalışmalar sınırlıdır. $\mathrm{Bu}$ konuda yapılan eğitimlerin daha fazla deneysel çalışmalar ile test edilmesi önerilebilir.

Ülkemizde illerde Sağlık Müdürlükleri bünyesinde Evde Sağlik Hizmetleri Koordinasyon Merkezleri bulunmaktadır. ${ }^{5}$ Evde sağlık hizmetine ihtiyacı olanlar toplum sağlığ merkezlerine, aile hekimlerine veya Türkiye
Kamu Hastaneleri Kurumuna eğitim araştırma hastanelerinde kurulmuş olan evde sağlik hizmeti birimlerine telefonla, sözlü veya yazılı olarak başvurmaktadır. Birim, randevu sistemi ile mesai saatleri içinde çalışmaktadır. ${ }^{5}$ Hastanın merkeze başvurusundan itibaren hastaya evde bakım hizmetinin aile hekimi tarafindan $\mathrm{m} 1$ yoksa sağlık kurumu bünyesinde çalışan birim tarafından mı verileceğine karar verilmektedir. ${ }^{13}$ Ailelerin \%86.7'sinin evde sağlık hizmetleri koordinasyon merkezine başvurduğu ancak yalnızca \%36.7'sinın bu birimlerden hizmet aldığı ve alınan hizmetin en çok \%23.3 oranında tıbbi tedavi veya izlem hizmeti olduğu görülmüsşür. Aileler taburculuğa hazırlansalar bile ülkemiz şartlarında en azından ilk bir ay hasta ve ailenin evde bakıma uyumunu sağlamak için evde hemşirelik bakımı verilmesi önerilmektedir.

Ülkemizde tıbbi teknolojiye bağımlı hastaların evde bakımını destekleyecek, tecrübeli evde bakım ekipleri yoktur. Bu hastaların bakımları aileler tarafindan yapılmaktadır. Ayar ve ark. ${ }^{13}$ evde bakılan çocuk hastaların bakımı ile ilgilenen birincil kişilerin çoğunlukla anneler olduğunu saptamıştır. Karataş $(2011)^{18}$ Rize'de yaptığ 1 araştırmada engelli çocukların çoğunlukla anneler tarafından bakıldığını belirlemiştir. Çalışma grubumuzdaki çocuklara benzer şekilde $(\% 90)$ anneler tarafindan bakılmakta olduğu saptanmıştır. Annelerin tamamının çalışmıyor olması ve babaların çalışıyor olması da bunu etkilemiş olabilir.

Tıbbi teknolojiye bağımlı hastalarının evde bakımını yapabilecek nitelikte 24 saat hizmet verebilecek hemşire veya doktorun olmaması nedeniyle bu hastaların evde bakımında ciddi sorunlar yaşanmakta ve komplikasyonlarla yoğun bakıma tekrarlayan başvurular artmaktadır., ${ }^{46}$ Yoğun bakımdan taburcu olduktan sonra evde bak1lmakta olan hastaların \%56.7'sinin yoğun bakıma tekrarlayan yatışları olmuştu. Ülkemizde evde bakım hizmeti veren ekibin ve evde bakım hizmetlerinin tıbbi teknolojiye bağımlı hastaların bakımı konusundaki yeterliliklerin gözden geçirilmesi ve bu konuda daha donanımlı hale getirilmeleri önerilebilir.

Uzun süre yoğun bakımda kalmaya bağl1 gelişen enfeksiyonların yatış süresini arttırdığı bilinmektedir. Hastane enfeksiyonlarından korunmak için stabil yoğun bakım hastasının evde bakımı önerilmektedir. ${ }^{19}$ Evde bakılan hastalarda enfeksiyonların daha az olduğu bildirilmektedir. ${ }^{1}$ Sovtic ve arkadaşları $(2012)^{20}$ 
mekanik ventilatöre bağımlı çocuklarda evde bakımın hastane enfeksiyonlarını önlediğini belirlemiştir. Ülgen Tekerek ve ark. ${ }^{1}$ ve Sovtic ve ark. ${ }^{20}$ nın sonuçlarına benzer şekilde çalışma grubumuzdaki ailelerin \%76.7'si evde enfeksiyonun daha az görüleceğini bildirmiştir.

Yoğun bakım üniteleri çocukların fizyolojik ve psikososyal açıdan gelişimlerine uygun değildir. Evde bakımın hastanedeki bakıma göre hasta ve aile için daha bağımsız olma ve yaşam kalitesinin artması için daha uygun olduğu bildirilmektedir. ${ }^{13-15}$ Literatürle uyumlu olarak ailelerin tamamı evde bakilan hastanın yaşam kalitesinin daha iyi olacağını, \%90'1 iyileşmesinin daha hızlı olduğunu ve \%60'1 ölmek üzere olan hastalar için fiziksel ve psikolojik rahatlığın evde sağlanacağını belirtmiştir.

Hastaların evde bakım maliyetlerinin, hastanede kalış maliyetlerine göre çok daha düşük olduğu, evde bakım hizmetlerinin amacının sağl1k hizmetlerinin maliyetini düşürmek ve verimini artırmak olduğu bildirilmektedir. Finansal kaynakların kıt olduğu gelişmekte olan ülkeler için evde bakımın desteklenmesi önerilmektedir. Evde bakım hizmetlerinin kamu kaynaklarıyla finanse edilmesi, sağlık giderlerinin kontrol altına alınması ve yataklı tedavi hizmetleriyle ilgili giderlerin azaltması açısından önemlidir. ${ }^{15}$ Ülkemizde Sağlık Bakanlığı birimlerince verilen evde bakım hizmetlerinde, hastalara yapılacak olan harcamalar günü birlik tedavi kapsamında, Sosyal Güvenlik Kurumu tarafindan ödenmektedir. Bu hastaların muayene, tedavi ve bakım1nda kullanilacak malzemelerine para ödememesi için evde bakım hizmetinin hastanelere bağlı evde sağlık birimlerinden alması gerekmektedir. ${ }^{5}$ Amerika'da yoğun bakımda mekanik ventilasyondaki günlük hasta bakımı maliyetinin 600-1500 dolar arasında değiştiğgi, ${ }^{10,11}$ aylık sağlık bakım maliyetinin 21,570 dolar olduğu, bu hastalar evde bakıldığında aylık 7,050 dolara mal olduğu bildirilmektedir. ${ }^{12}$ Çalışma grubumuzdaki ailelerin $\% 73$ 'ü tedavi ve bakım maliyetinin yoğun bakımda daha düşük olduğunu belirtmişti. Ottonello ve ark. ${ }^{14}$ ve Ülgen Tekerek ve ark. ${ }^{1}$ evde mekanik ventilasyon (EMV) uygulanan hastalar için maliyet analizi yapmış, her iki araştırıcı EMV uygulanan hastalara evde profesyonel hemşirelik bakım desteği eklendiğinde dahi evde bakımın daha ekonomik olduğunu belirlemiştir. Hasta grubumuzda evde bakım ve yoğun bakımdaki bakım ile ilgili bir maliyet analizi yapılmamıştır. Ailelerin evde bakımı daha maliyetli olarak algılamasında, hastaların bakımında kullanılan birçok malzemenin aileler tarafindan ücretli alınmas1, sosyal güvenlik kurumundan karşılanmamış olması etkilemiş olabilir. Ülkemizde hastaların yoğun bakım ve evde bakımındaki günlük veya aylık maliyetlerinin belirlenmesi için daha detaylı çalışmaya gereksinim vardır.

Ülkemizde bakıma muhtaç hastaya bakmakla yükümlü olan kişilere aynı evde yaşamas1 koşulu ile ücret ödenmektedir. ${ }^{13,17}$ Hastalarımızın ailelerinin \%60'1 çocuklarının bakımı için maddi destek aldığını belirtmiştir. Ayar ve ark. (2015)'nın Ankara'da yaptığ 1 çalışmada ailelerin \%90.5'inin bakıcı maaşı aldığını saptamıştır. ${ }^{13} \mathrm{Bu}$ çalışma ile karşılaştırıldığında çalışmamızda maddi destek alan ailelerin oranının daha düşük olduğu saptandı. $\mathrm{Bu}$ farkın ailelerin sosyal hakları konusundaki farkındalığının düşük olması veya bakıcı maaşı almaya yönelik kriterleri karşılayamamasından kaynaklandığı düşünülebilir.

Evde bakımın iyi bir eğitim ve ciddi kontrol gerektirdiği, kompleks hastalara acil durumlarda hemen müdahale edecek profesyonel kişilerin olmamas1 veya ailenin eğitilmemesi durumunda hastaların tedavisinde sorunlar olabileceği, kritik durumlarda geri döndürülemeyecek sonuçlara yol açabileceği bildirilmektedir. ${ }^{5,13,21}$ Literatürde belirtildiği gibi çalışma grubumuzdaki ailelerinde büyük çoğunluğu (\%93.3) evde acil durumlarda geri döndürülemeyecek sonuçlar olacağını belirtmişti. Yoğun bakımdan taburcu edilen hasta evde bakılmaya başlandığında olası riskleri erkenden belirlemek için bakımdan sorumlu kişilerin eğitilmesi, hastaların yakından veya görüntülü olarak izlenmesi için takip sistemleri olmalıdır. Ancak ülkemizde halen bu hastaların izlenmesi için uygun bir sistem bulunmamaktadır ve bu büyük bir gereksinimdir.

Sonuç: Evde bakılan tıbbi teknolojiye bağıml, komplike hasta çocukların sayısı her geçen gün artmaktadır. Yoğun bakımdan taburcu edilen teknolojiye bağımlı çocuklar evde sağlık hizmetleri koordinasyon merkezinden yeterince destek alamamaktadir. $\mathrm{Bu}$ hastaların evde bakımları aileleri tarafindan yapılmaktadır. Tıbbi teknolojiye bağımlı çocuk ve ailenin fiziksel, duygusal, sosyal, ekonomik ve çevresel tüm boyutlarıyla değerlendirilmesi ve planlı bir ekip çalışması yapılması gerekmektedir. Tıbbi teknolojiye bağımlı hastaların evde bakımında 
yaşanan güçlüklerin değerlendirildiği çok merkezli, kapsamlı çalışmaların yapılması ve ülkemiz için evde bakım hizmetlerinin geliştirilmesi önerilebilir.

\section{Kaynaklar}

1. Ülgen Tekerek N, Dursun A, Aky1ldız BN. Çocuklarda ev tipi mekanik ventilasyon uygulamaları:Erciyes Üniversitesi deneyimi. Türk Yoğun Bakım Derneği Dergisi, 2017;15 (1):28-33.

2. Preutthipan A. Home mechanical ventilation in children. Indian J Pediatr. 2015;82 (9):852859.

3. Köroğlu T, Bayrakçı B, Dursun D, Kendirli T, Yıldızdaş D, Karaböcüoğlu M. Çocuk yoğun bakım birimleri için kılavuz:çocuk acil tıp ve yoğun bakım derneği önerileri. Türk Pediatri Arşivi, 2006;41:139-145.

4. Sönmez Düzkaya D, Bozkurt G. Yoğun Bakım Hastasının Evde Bakımı. Yoğun Bakım Hemşireliği Dergisi, 2012;16(1):21-8

5. Aksoy H, Kahveci R, Şencan İ, Kasım İ, Özkara A. Evde bakım hizmetlerine genel bakış ve Türkiye'deki mevcut durum. Turk Med J, 2015; 7(2): 162-168.

6. Lloyd-Owen SJ, Donaldson GC, Ambrosino $\mathrm{N}$, Escarabill J, Farre R, Fauroux B, et al. Patterns of home mechanical use in Europe: Results from the Eurovent survey. Eur Respir J, 2005;25(6):1025-31.

7. Garner DJ, Berlowitz DJ, Douglas J, Harkness N, Howard M, McArdle N, et al. Home mechanical ventilation in Australia and New Zealand. Eur Respir J, 2013; 41: 39-45.

8. Nasilowski J, Szkulmowski Z, Migdal M, Andrzejewski W, Drozd W, CzajkowskaMalinowska M, et al. Prevalence of home mechanical ventilation in Poland. Pneumonol. Alergol. Pol, 2010;78, 6: 392-398.

9. Oktem S, Ersu R, Uyan ZS, Cakir E, Karakoc F. Karadağ B, et al. Home ventilation for children with choronic respiratory failure in Istanbul. Respiration 2008;76;76-

10.Kahn JM, Rubenfeld GD, Rohrbach J, Fuchs BD. Cost savings attributable to reductions in intensive care unit length of stay for mechanically ventilated patients. Med Care, 2008; 46:1226-1233

11.Dasta JF, McLaughlin TP, Mody SH, Piech CT. Daily cost of an intensive care unit day: The contribution of mechanical ventilation. Crit Care Med, 2005; 33:1266-1271.

12.National Association for Homecare and Hospice: Basic Statistics About Home Care;
Updated 2008. Washington, DC. The National Association for Home Care and Hospice; 2008. 13. Ayar G, Şahin Ş, Uysal Yazıcı M, Gündüz RÇ, Yakut HI, Demirel F. Çocuk Hastalarda Evde Bakım Hizmetlerinin Değerlendirilmesi. Türkiye Çocuk Hastalıkları Dergisi, 2015; 1: 1217

14. Ottonello G, Ferrari I, Pirroddi IMG, Diana MC, Villa G, Nahum L, et al. Home mechanical ventilation in children: retrosceptive survey of a pediatric population. Pediatrics International, 2007;49, 801-805.

15.Özer Ö, Şantaş F. Kamunun Sunduğu Evde Bakım Hizmetleri ve Finansmanı. Acıbadem Üniversitesi Sağlık Bilimleri Dergisi, 2012; 3(2): 96-103.

16.Elias ER, Murphy NA. Home care of children and youth with complex health care needs and technology dependencies. Pediatrics, 2012;129:996-1005.

17.Bakım Hizmetleri Stratejisi ve Eylem Planı (2011-2013). Resmi Gazete, Basım tarihi: 19.01.2011, Bölüm 2;119:6:1.

18. Karataş Z. Evde Bakım Hizmeti Sunan Aile Bireyi Bakıcıların Moral ve Manevi Değerlerinin Başa çıkmadaki Etkisi. Rize Üniversitesi, Sosyal Bilimler Enstitüsü, Yüksek Lisans Tezi, 2011, Rize

19. Yılmaz M, Sametoğlu F, Akmeşe G, Tak A, Yağbasan B, Gökçay S ve ark. Sağlık hizmetinin alternatif bir sunum şekli olarak evde hasta bakımı. Istanbul Med J, 2010;11(3):125-132.

20.Sovtic A, Minic P, Vukcevic M, MarkovicSovic G, Rodic M, Gajic M. Home mechanical ventilation in children is feasible in developing countries. Pediatr Int, 2012;54:676-81.

21.McIntosh J, Runciman P. Exploring the role of partnership in the home care of children with special health needs: Qualitative findings from two service evaluations. Int J Nurs Stud, 2008;45:714-26. 